\title{
A Comparative Study of Jet Airways and Indigo Airline Employee's Motivation in Context With "Hygiene Factor"
}

Neha Nazneen Siddiqui, Integral University, India

Gaurav Bisaria, Integral University, India

\begin{abstract}
In this paper, effective human resource management practices and their impact on airline ground staff have been studied. The aviation industry's attrition rates have multiplied in the most recent years in the entry and mid-administration level. It is occurring because of the view of being poor paymasters, delay in pay rates, work uncertainties, and little concern for worker welfare factors; for example, attractive and distinct pay packages with incentives and working conditions appear to be progressively moderate and controlled in regions of aviation. It is needed to know what aspects have changed over time to bridge the employee's expectations. In this paper, different factors of motivation have been analyzed. It has been attempted to discover the innovative techniques of motivation to retain the talent and offer some suggestions to lower the attrition rates of the ground staff of airlines at Lucknow Airport.
\end{abstract}

\section{KEYWORDS}

Attrition, Aviation, Employee Motivation, Retention

\section{INTRODUCTION}

Attrition can be a smoldering downfall for the airline sector, particularly due to failing to tap the full use of human capital and losing much of its resources and money. Productivity for relative organisation or association may be an essential issue (Siddiqui \& Bisaria, 2018). There are many factors answerable for influencing the productivity of a company (Siddiqui \& Bisaria, 2019). Employee attrition is one of all those considered today to be one of all the toughest market challenges. Top management personnel, human resources specialists, and business analysts, etc., have paid heed to the effects of attrition. Numerous companies worldwide have identified this to be one of the foremost costly and seemingly obdurate human resource problems ("Employee retention," 2017; Siddiqui \& Bisaria, 2019).

\section{Conceptual Framework}

\section{Herzberg's Two-Factor Theory}

Psychologist Frederick Herzberg developed the Two-Factor Theory of motivation (otherwise known as a dual-factor theory or motivation-hygiene theory) in the 1950s. Frederick Herzberg developed the 
model in 1959. He did this by interviewing over 200 professionals. The interviews delved into when the interviewees were at their most and least happy with their jobs. Herzberg's Motivation Theory model goes by several different names, including Two-Factor Theory, Herzberg's Motivation-Hygiene Theory, and Duel Structure Theory (Herzberg, 1959). These factors are:

- Motivators: Those who can encourage employees to work harder. The presence of motivators causes employees to work harder. They are found within the actual job itself.

- Hygiene Factors: These will not encourage employees to work harder. However, they will cause them to become unmotivated if they are not present. The absence of hygiene factors will cause employees to work less hard. Hygiene factors are not present in the actual job itself but surround the job.

\section{STATEMENT OF PROBLEM}

In the modern competitive world, business organizations face ever-growing challenges regarding commitment, engagement, belief, and employee retention. Multiple studies in different countries and across industries show that employees passionate about their jobs and their organizations are in the minority. The global airline industry is facing various challenges. One of the major challenges is related to the turnover of highly skilled Ground staff. The disaffection level is viewed as a direct predictor of employee turnover with the current job. The turnover intention of employees is heavily affected by Hygiene Factors viz existing pay, job security, working conditions, status, policy and administration, relationship with subordinates and supervisor, etc.

\section{AIM OF THE STUDY}

The research aims to find out the emerging techniques of motivation to retain the right talent and offer some suggestions to lower down the attrition rate in Jet Airways and Indigo Airlines using Hygene Factor as a tool.

Figure 1. Herzberg's Motivation-Hygiene Theory

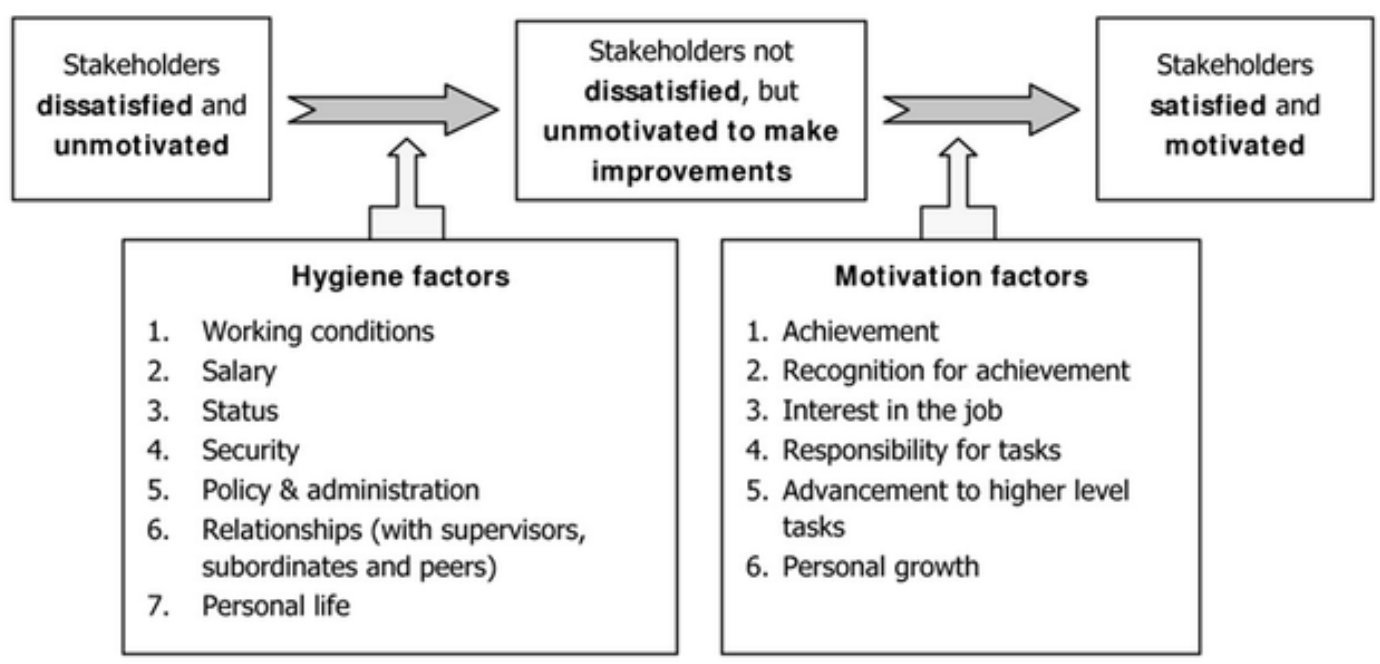




\section{OBJECTIVE OF THE STUDY}

A comparative study of Jet and Indigo airline employees in context with Hertzberg two factor theory, i.e., "HYGIENE" (Two-factor theory by Herzberg) factors:

Objective 1: To compare Jet and Indigo airline employees' motivation by "Quality of supervision." Objective 2: To compare Jet and Indigo airline employees' motivation by "Salary Structure."

Objective 3: To compare Jet and Indigo airline employees' motivation by "physical working condition."

Objective 4: To compare Jet and Indigo airline employees' motivation by “Job Security."

\section{HYPOTHESIS BASED ON “HYGIENE” FACTORS}

H1: Indigo Airline employees are more satisfied as "Quality of supervision" at the workplace is more in Indigo Airline in comparison to Jet Airways and vice versa.

H2: Indigo Airline employees are more satisfied as "salary Structure" at the workplace is more in Indigo Airline in comparison to Jet Airways and vice versa.

H3: Indigo Airline employees are more satisfied as "Physical working conditions" at the workplace are more in Indigo than Jet Airways and vice versa.

H4: Indigo Airline employees are more satisfied as "Job Security" at the workplace is more in Indigo Airline than Jet Airways and vice versa.

\section{SIGNIFICANCE OF THE STUDY}

It is needed to know what aspects have changed over time to bridge the employee's expectations to retain them. The research result will help lay the foundation for changing employees' needs and expectations, lowering the attrition rate. It will help the industry to know the changing expectation and the way to know how to fill the expectation gap.

This study will help the Administrators/policymakers to understand the perspectives of employees working in the organization. This study will help Human Resources (HR) managers in devising the right strategy in talent management. It will also help in understanding if any changes in HR policy are required for employee retention. This study will also help employees, not expressive enough to show their dissatisfaction within the organization. This particular study will help Aviation sector employees and all other service sector employees because there are some similarities like work and process. This study will also benefit the Chief Executive Officer (CEO) and corporate owners. It will provide them information on the importance of knowing the major factors behind employee dissatisfaction and their company's probable effect. The study will also benefit the research scholars because they know the different causes of employee turnover and work as a base for further research if they want to pursue the work in the same field.

\section{BACKGROUND}

The term motivation comes from the Latin meant to move (Kreitner \& Kinicki, 2012). "The psychological process that induces the arousal, direction, and persistence of goal-oriented voluntary actions" is the motivation (Mitchell, 1982). As described by Robbins and Judge (2007), motivation is the "willingness to exert high levels of effort to organisation goals, conditioned by the ability of the effort to meet certain individual needs." In this case, a need is an internal condition that makes those findings look attractive. An unmet need causes tension that triggers the urge inside the individual. 
These causes then produce search behavior to identify precise targets that would meet the need if satisfied and lead to stress reduction (Robbins \& Judge, 2007).

\section{The Definition of Review of Employee Retention}

Employee retention refers to policies and practices that companies use to prevent valuable employees from leaving their job. It involves taking measures to encourage employees to remain in the organization for a maximum time (Bazan, 2011). Hiring knowledgeable people for the job is essential for an employer (Ranjbar \& Amiri, 2015). Nevertheless, retention is even more important than hiring. It is true, as many employers have underestimated costs associated with key staff turnover (Ahlrichs, 2000). Turnover costs can be incurred with reference checks, security clearance, temporary worker costs, relocation costs, formal training costs, and induction expenses (Kotzé and Roodt, 2005).

The literature review offers the ability for employee research to encourage evidence correlated with what has already been accomplished and conducted for employee retention. This literature review's fundamental goal is to analyze the factors impacting the retention of workers in the aviation industry ("Employee retention," 2017).

The retention of employees is significant to the development and the accomplishment of an organization's goals and objectives. Retention of employees can be a vital source of competitive advantage for any organization (Ahammad, 2016; Boswell, 2017; Zarim, 2017). Today, changes in technology, global economics, and trade agreements directly affect employee/employer relationships. Until recently, loyalty was the cornerstone of that relationship. The loss of talented employees may be very detrimental to the company's future success. Outstanding employees may leave an organization because they become dissatisfied, underpaid, or unmotivated. While trying to retain employees within the organization, they may present other challenges as well (Ritz, 2016; Robinson, 2014; Zheng, 2016). They may demand higher wages, may not comply with organization practices, and interact well with their co-workers or comply with their managers' directions (Said, 2012).

Besides these problems, asymmetric information or lack of information about the employees' performance may complicate an organization's endeavor to retain productive employees. Without adequate information, an organization may not be able to distinguish productive workers from nonproductive ones. Employees often may take credit for the successes and deflect failures to other employees. This issue is known as a moral hazard problem. In many instances, companies may reward or punish employees for an organization's outcome for which they had no impact (Bakker, 2017; Terera, 2014).

Non-productive and productive workers receive the same or nearly the same compensation and package of perks because of management's inability to distinguish talented employees from the rest of the organization's labor force. Attempting to keep talented workforce members is further complicated because of bounded rationality (Memon, 2010). It is another result of asymmetric information. Both the manager does not know what to ask from the employee, and the employee does not know what to provide. Therefore, productive workers cannot distinguish themselves from non-productive coworkers (Ongori H., 2008; Collins, 2007).

Human resources, in general, are related to the building of morale for the employees. The research found that one must start by finding a motivation that makes that employee satisfied at work and satisfied with the organization for a person with the good work quality. This concept is in line with Fredrick Herzberg's two-factor theory, which describes the motivation to create a quality of worklife, namely motivator factors or internal motivation directly related to work. Another one is hygiene factors or external motivation, which are components related to operations that are not an incentive but can make people satisfied or dissatisfied with the work. If the employees have responded to the motivation, it will make them satisfied with the work.

\section{Review of Literature on Employee Retention in the Aviation Industry}

In this section, literature related to retention strategies of the aviation sector is discussed: 
- Mehta (2020) described attrition and retention of employees as probably the biggest challenge in the Civil Aviation Industry. It involves a high level of emotional work. To win against this challenge, organisations have been focusing on the job satisfaction of employees. It has been found in the literature that employees' job satisfaction is significantly related to personal, social, interpersonal, and organisational factors.

- Satardien et al. (2019) described Employees value opportunities that allow them to exercise their discretion in decision-making and partake in privileged communication and positive recognition of their work through praise or positive comments. The organisation would benefit from evaluating possible reasons other than perceived support and organisational commitment, which could account for this turnover and consider the organisation's recommendations. Given the high rate of turnover in the organisation under investigation, cultivating organisational commitment through organisational support is likely to increase stability in the aviation industry.

- Alafeshat \& Tanova (2019) explains that high-performance work systems (HPWS) help the employees to feel that the organization places more importance on their talents, achievements, and development with its HR policies and practices. In turn, they feel obliged to reciprocate by becoming more engaged, which leads to higher satisfaction levels and intentions to stay in the organization.

- Uniyal et al. (2018) evaluated to retain good employees. There is a call for the management of the Airlines Industry to initiate programs for improving embeddedness. Fostering a cordial manageremployee relationship, clarity in communication, and prompt feedback system in operational terms are ways of bringing positive employee links with the organization. Very often, innovative benefits in the form of flexibility and qualitative compensation act as major contributors to a good fit of the employee to the organization.

- Turney (2017) describes that the new diversity invites us to consider the influence of various cultures, belief systems, and values as we design an effective and efficient training program for multinationals. Moreover, He has identified cross-cultural issues, gender differences, ethnic and minority consideration that affects the aviation environment.

- Karatepe (2016) suggested that if ground staff members are satisfied with their current organization's career, display creative performance and reduced lateness attitude.

\section{Aviation Industry Overview}

To a great extent, India's aeronautics industry is undiscovered with great development openings, considering that air transport is as yet costly for most of the nation's populace. Almost 40 percent is the upwardly versatile white-collar class. The business partners ought to connect with and team up with policymakers to execute proficient and sound choices to help India's thoughtful flying industry. With the right arrangements and persevering spotlight on quality, cost, and traveler premium, India would be broad set to accomplish its vision of turning into the third-biggest avionics advertising by 2025 .

India's passenger traffic grew at $16.52 \%$ year on year to achieve 308.75 million in FY18. It grew at a CAGR (Compound Annual Growth Rate) of $12.72 \%$ throughout FY(Financial Year) 06FY18. Domestic passenger traffic grew year on year by $18.28 \%$ to achieve 243 million in FY18 and is anticipated to become 293.28 million in FY20E. India's international and domestic aviation sector developed 14.40 percent year on year and 9.40 percent year to $1,886.63$ thousand and 437.93 thousand amid 2017-18.

\section{Indian Aviation Industry Report}

In the last three years, the aviation industry has evolved as being among the country's fastest-growing sectors. India is widely considered the third biggest market in the world for regional commercial aviation. India has become the world's third-largest regional commercial aviation industry. It is 
anticipated to surpass Britain by 2024 to be the third biggest market for air travelers ("Indian Aviation Industry I Aviation Industry at A Glance in 2019-2020", 2020).

\section{Market Size}

In FY20 (until January 2020), Indian passenger traffic stood at 293.99 million, with regional traffic volumes reaching 235.44 million and international passenger traffic crossing 58.55 million.

Domestic cargo traffic registered at 1.14 million tonnes in FY20 (until January 2020), although international cargo traffic stood at 1.70 million tonnes. In FY20 (until January 2020), India's overseas and regional movements hit 0.37 million and 1.2 million, respectively ("Indian Aviation Industry I Aviation Industry at A Glance in 2019-2020", 2020). It is projected that the number of aircraft will rise to 1,100 by 2027 (“Indian Aviation Industry I Aviation Industry at A Glance in 2019-2020”, 2020).

\section{Introduction to Indigo Airline}

IndiGo, based in Gurgaon, is a low-cost carieer (LCC). It is the country's biggest airline by customers and fleet capacity, with a market dominance of 39.7 percent since about January 2018("IndiGo," 2020). That is also the largest LCC, at over 46 million passengers traveling in 2017, jet fleet size and passengers flown, and the 7th biggest airline in Asia. The carrier flies to 50 domestic and overseas destinations. It has its main hub at Delhi International Airport, India.

\section{Introduction to Jet Airways}

Jet Airways was a big full-service international Indian airline headquartered in Mumbai. In October 2017, with 17.8 percent market dominance, it was India's second-largest carrier behind IndiGo. It had run more than 300 flights every day to 68 destinations from its various hubs all over India ("Jet Airways," 2017).

Fully integrated as a limited liability company in 1992, the carrier started functioning in 1993 as just an air taxi service. Full-fledged flights started in 1995, with the addition of international sectors in 2004. In 2005 and 2007, the carrier decided to go public, purchasing Air Sahara. In 2010, it was the nation's biggest carrier by passenger market dominance, a place it retained since 2012("Jet Airways," 2017).

\section{Introduction to Ground Service Workers (GSW)}

This study has been conducted on-ground staff Employees of Jet and Indigo Airlines at Chaudhary Charan Singh Airport, Lucknow. Ground Staff Workers play a significant role in the aviation industry. They ensure passengers' safety, security, and comfort, oversee the loading and unloading of cargo and baggage and prepare aircraft for flight. Their level of organisation determines how smoothly the flight process will be for passengers and flight crew. Many ground service workers were needed to maintain aircraft, process and transport baggage and cargo, prepare food for flights, refueling planes, and perform countless other tasks ("Ground Staff Job Description,” 2019).

\section{Ground Staff Job Description}

In the airline sector, ground staff or ground personnel work in diverse capacities at the airport. Ground Staff maintains passenger safety and convenience by inspecting luggage, delivering information, assisting passengers with disabilities, verifying bookings, and selling tickets.

In general, airlines are searching for enthusiastic ground workers responsible for logistical tasks and customer contact. They are responsible for greeting passengers, delivering information, facilitating passengers with disabilities, traveling with young children, checking baggage, bookings, and selling tickets. One must answer customer questions quickly and guarantee convenience for all travelers ("Ground Staff Job Description," 2019). 


\section{RESEARCH GAP}

After reviewing the literature available, the research study has only been found on employees' motivation in banking, finance, education, hotel, and retail industry. Nonetheless, no significant study has been done on airline industry employees, especially in India.

In a few of the literature, employee motivation and retention techniques on crew members have been done, but very little research has been done, on-ground staff employees. Most of the researchers have focused on employee retention of crew members and ignored ground staff employees. No proper evidence has been found regarding any research study to determine ground staff employees' motivational levels working at Lucknow Airport.

Therefore, this topic has been decided for the research to fill the gap.

\section{RESEARCH METHODOLOGY}

The descriptive research design was employed to compare the motivational level of Jet and Indigo Airline employees. The target population was comprised of 200 ground staff of Jet and Indigo staff at Lucknow Airport. The study developed the questionnaire, which was administered to the target population through personal contact. Some of the questions required respondents to indicate their level of agreement or disagreement with the research model factors:

- Population: Employees of Indigo and Jet airways working at Lucknow airport.

- Sources of Data: Primary: Primary data will be collected through the personal interview (Telephonic, Face to face), survey, and questionnaire.

- Respondent Profile: Ground staff of Indigo and Jet Airline working at Lucknow airport.

- Sampling Techniques: Simple Random Sampling (SRS) of probability sampling has been used.

- Type of Research: Descriptive research has been done.

- Sample Size and Data Collection Methods: This study has been conducted on 200 employees working in Indigo and Jet Airways at Lucknow Airport.

- Hypothesis Testing Tool: Descriptive statistics like frequencies, crosstab, and ratios have been applied for analysis and interpretation. Pie charts and bar diagrams etc. Hypothesis testing using the "Mann Whitney U test," whereas proportions and comparison will be measured using the Cross tab.

- Primary and Secondary Data Collection: Questionnaires have been used to collect Airline employees' information on ground staff. Most of the time, a personal interview has been conducted to gather information. Sometimes, due to staff's unavailability, the questionnaire has been handed over to the HR manager of Jet Airways and Indigo Airline to be distributed to both the Airlines' ground staff employees.

- Sources of Secondary Data: The relevant secondary data was taken from various reputed journals, magazine, newspapers, books, conferences proceedings, a college library, books, and data taken from Various Websites: Airport Authority of India, Ministry of Civil Aviation, and Directorate General of Civil Aviation, World Tourism Organisation (WTO), Airport Authority of India (AAI).

- Statistical Tools Used: Statistical analysis was done using Statistical Package for Social Science (SPSS) version 25. The following statistical tools were employed to prove the hypothesis.

\section{ANALYSIS AND DISCUSSIONS}

In this section, employees of Jet Airways and Indigo Airlines were requested to indicate their agreement or disagreement towards different hygiene factors of Herzberg's theory of motivation. 
Table 1. Reliability Statistics

\begin{tabular}{|l|l|l|}
\hline Cronbach's Alpha & \multicolumn{1}{|c|}{$\begin{array}{c}\text { Cronbach's Alpha Based on } \\
\text { Standardized Items }\end{array}$} & N of Items \\
\hline .814 & .833 & 35 \\
\hline
\end{tabular}

Table 2. Mann-Whitney Test-Quality of Supervision

\begin{tabular}{|l|l|l|l|l|}
\hline \multicolumn{2}{|c|}{ Ranks } \\
\hline & \multicolumn{1}{|c|}{ Name of organisation } & \multicolumn{1}{|c|}{ N } & \multicolumn{1}{c|}{ Mean Rank } & \multicolumn{1}{c|}{ Sum of Ranks } \\
\hline \multirow{3}{*}{$\begin{array}{l}\text { Does your work get supervised at } \\
\text { every level in your organisation? }\end{array}$} & Indigo & 100 & 66.72 & 6671.50 \\
\cline { 2 - 5 } & Jet Airways & 100 & 134.29 & 13428.50 \\
\cline { 2 - 5 } & Total & 200 & & \\
\hline
\end{tabular}

Table 3. Test Statistics-Quality of Supervision

\begin{tabular}{|l|l|}
\hline \multicolumn{2}{|c|}{ Test Statistics $^{\mathbf{a}}$} \\
\hline & $\begin{array}{c}\text { Does your work get supervised at every level } \\
\text { in your organisation? }\end{array}$ \\
\hline Mann-Whitney U & 1621.500 \\
\hline Wilcoxon W & 6671.500 \\
\hline Z & -8.822 \\
\hline Asymp. Sig. (2-tailed) & .000 \\
\hline
\end{tabular}

a. Grouping Variable: Name of organisation

\section{Table 4. Cross tab-Quality of Supervision}

\begin{tabular}{|c|c|c|c|c|c|c|c|c|}
\hline \multicolumn{9}{|c|}{ Name of organisation * Does your work get supervised at every level in your organisation? Cross tabulation } \\
\hline & & & \multicolumn{5}{|c|}{ Does your work get supervised at every level in your organisation? } & \multirow{2}{*}{ Total } \\
\hline & & & Frequently & Sometimes & Occasionally & Rarely & Never & \\
\hline \multirow{6}{*}{$\begin{array}{l}\text { Name of } \\
\text { organisation }\end{array}$} & \multirow{3}{*}{ Indigo } & Count & 68 & 24 & 3 & 1 & 4 & 100 \\
\hline & & $\begin{array}{l}\% \text { within Name } \\
\text { of organization }\end{array}$ & $68.0 \%$ & $24.0 \%$ & $3.0 \%$ & $1.0 \%$ & $4.0 \%$ & $100.0 \%$ \\
\hline & & $\%$ of Total & $34.0 \%$ & $12.0 \%$ & $1.5 \%$ & $0.5 \%$ & $2.0 \%$ & $50.0 \%$ \\
\hline & \multirow{3}{*}{$\begin{array}{l}\text { Jet } \\
\text { Airways }\end{array}$} & Count & 13 & 15 & 71 & 0 & 1 & 100 \\
\hline & & $\begin{array}{l}\% \text { within Name } \\
\text { of organization }\end{array}$ & $13.0 \%$ & $15.0 \%$ & $71.0 \%$ & $0.0 \%$ & $1.0 \%$ & $100.0 \%$ \\
\hline & & $\%$ of Total & $6.5 \%$ & $7.5 \%$ & $35.5 \%$ & $0.0 \%$ & $0.5 \%$ & $50.0 \%$ \\
\hline \multirow{3}{*}{\multicolumn{2}{|c|}{ Total }} & Count & 81 & 39 & 74 & 1 & 5 & 200 \\
\hline & & $\begin{array}{l}\% \text { within Name } \\
\text { of organization }\end{array}$ & $40.5 \%$ & $19.5 \%$ & $37.0 \%$ & $0.5 \%$ & $2.5 \%$ & $100.0 \%$ \\
\hline & & $\%$ of Total & $40.5 \%$ & $19.5 \%$ & $37.0 \%$ & $0.5 \%$ & $2.5 \%$ & $100.0 \%$ \\
\hline
\end{tabular}

Source: (Data Collected through a questionnaire at Lucknow Airport, 2018) 


\section{Hypothesis (Quality of Supervision)}

H0: There is no difference between Jet Airways and Indigo Airline employees' motivation based on the "Quality of Supervision" factor.

\section{Interpretation (Quality of Supervision)}

The result suggests that the Mann Whitney $U$ test is at a significant level. Thus the null hypothesis is rejected, and the alternate hypothesis is accepted at a 5\% level of significance or $95 \%$ confidence level. The result shows a significant difference based on the "Quality of supervision" provided by Indigo and Jet Airways to their employees:

- Tabulated P value is $0.00<0.05->$ statistically significant difference.

- Indigo employees' work gets supervised frequently than Jet airways employees.

- It clearly shows that $68 \%$ of employees of Indigo Airlines said their work always gets supervised frequently. In contrast, only $71 \%$ of employees of Jet Airways affirmed that their work gets supervised occasionally.

Supervision is a maintenance factor that results in employee satisfaction; thus, we can say Indigo employees are more satisfied in terms of supervision at the workplace than Jet Airways employees.

\section{Hypothesis (Salary Structure)}

H0: There is no difference between Jet Airways and Indigo Airline employees' motivation based on the "Salary Structure" factor.

Figure 2. Bar Chart- Quality of Supervision

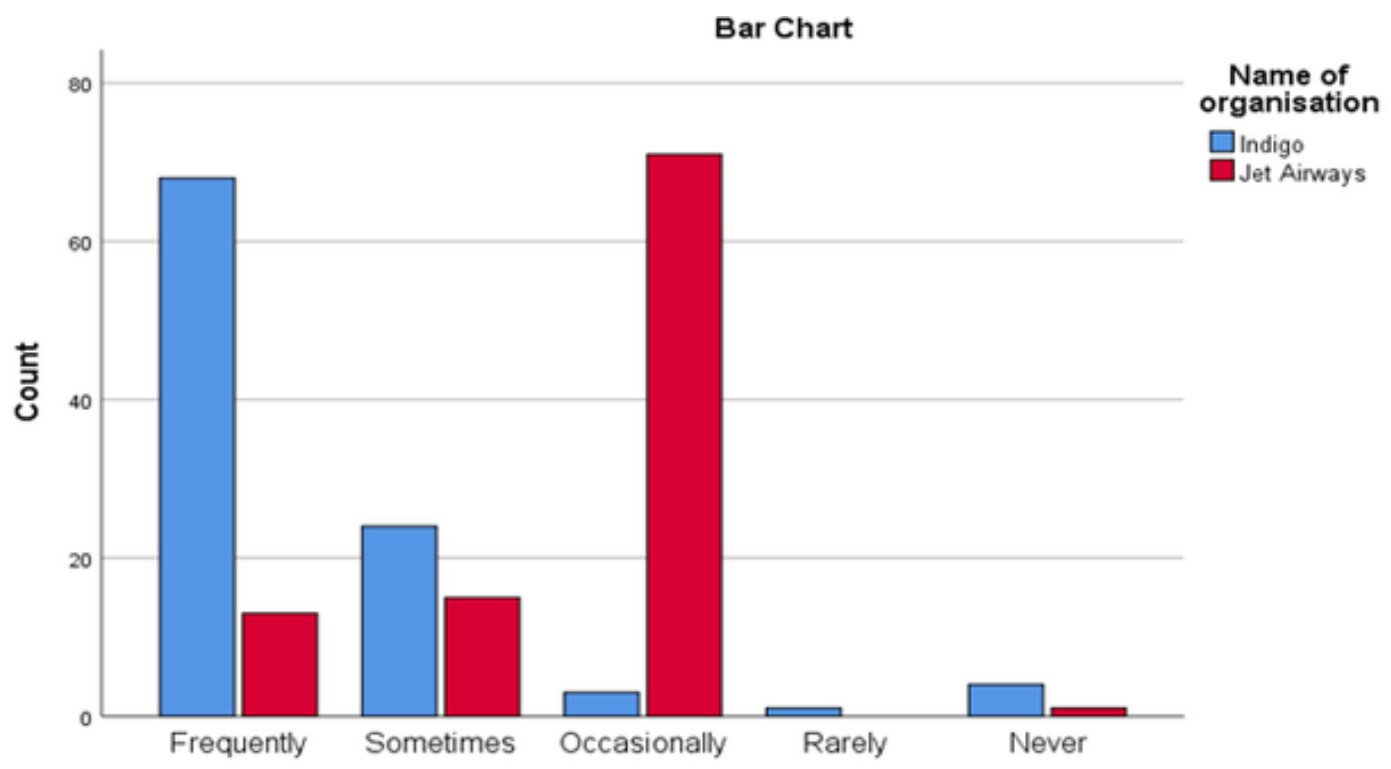

Does your work get supervised at every level in your organization? 
Table 5. Mann-Whitney Test-Salary Structure

\begin{tabular}{|l|l|l|l|l|}
\hline \multicolumn{5}{|c|}{ Ranks } \\
\hline & \multicolumn{1}{|c|}{ Name of organisation } & \multicolumn{1}{|c|}{ N } & \multicolumn{1}{c|}{ Mean Rank } & \multicolumn{1}{c|}{ Sum of Ranks } \\
\hline \multirow{3}{*}{$\begin{array}{l}\text { Do you satisfied with your } \\
\text { current salary structure? }\end{array}$} & Indigo & 100 & 89.00 & 8900.00 \\
\cline { 2 - 5 } & Jet Airways & 100 & 112.00 & 11200.00 \\
\cline { 2 - 5 } & Total & 200 & & \\
\hline
\end{tabular}

Table 6. Test Statistics -Salary Structure

\begin{tabular}{|c|c|}
\hline \multicolumn{2}{|c|}{ Test Statistics $^{\mathrm{a}}$} \\
\hline & $\begin{array}{c}\text { Do you satisfied with your current salary } \\
\text { structure? }\end{array}$ \\
\hline Mann-Whitney U & 3850.000 \\
\hline Wilcoxon W & 8900.000 \\
\hline $\mathrm{Z}$ & -3.464 \\
\hline Asymp. Sig. (2-tailed) & .001 \\
\hline
\end{tabular}

a. Grouping Variable: Name of organisation

\section{Table 7. Cross tab -Salary Structure}

\begin{tabular}{|c|c|c|c|c|c|}
\hline \multicolumn{6}{|c|}{ Name of organisation * Do you satisfied with your current salary structure? Cross tabulation } \\
\hline & & & \multicolumn{2}{|c|}{$\begin{array}{c}\text { Do you satisfied with your current } \\
\text { salary structure? }\end{array}$} & \multirow{2}{*}{ Tota } \\
\hline & & & Yes & No & \\
\hline \multirow{6}{*}{ Name of Organisation } & \multirow{3}{*}{ Indigo } & Count & 79 & 21 & 100 \\
\hline & & $\%$ within Name of organisation & $79.0 \%$ & $21.0 \%$ & $100.0 \%$ \\
\hline & & $\%$ of Total & $39.5 \%$ & $10.5 \%$ & $50.0 \%$ \\
\hline & \multirow{3}{*}{ Jet Airways } & Count & 56 & 44 & 100 \\
\hline & & $\%$ within Name of organisation & $56.0 \%$ & $44.0 \%$ & $100.0 \%$ \\
\hline & & $\%$ of Total & $28.0 \%$ & $22.0 \%$ & $50.0 \%$ \\
\hline \multirow{3}{*}{ Total } & & Count & 135 & 65 & 200 \\
\hline & & $\%$ within Name of organisation & $67.5 \%$ & $32.5 \%$ & $100.0 \%$ \\
\hline & & $\%$ of Total & $67.5 \%$ & $32.5 \%$ & $100.0 \%$ \\
\hline
\end{tabular}

Source: (Data Collected through a questionnaire at Lucknow Airport, 2018)

\section{Interpretation (Salary Structure)}

The result suggests that the Mann Whitney $U$ test is at a significant level. Thus the null hypothesis is rejected, and the alternate hypothesis is accepted at a 5\% level of significance or $95 \%$ confidence level. The result shows a significant difference based on "Pay "provided by Indigo and Jet Airways to their employees.

- Tabulated P value is $0.01<0.05->$ statistically significant difference.

- Indigo employees seem more motivated about "Salary Structure" than Jet Airways employees. 


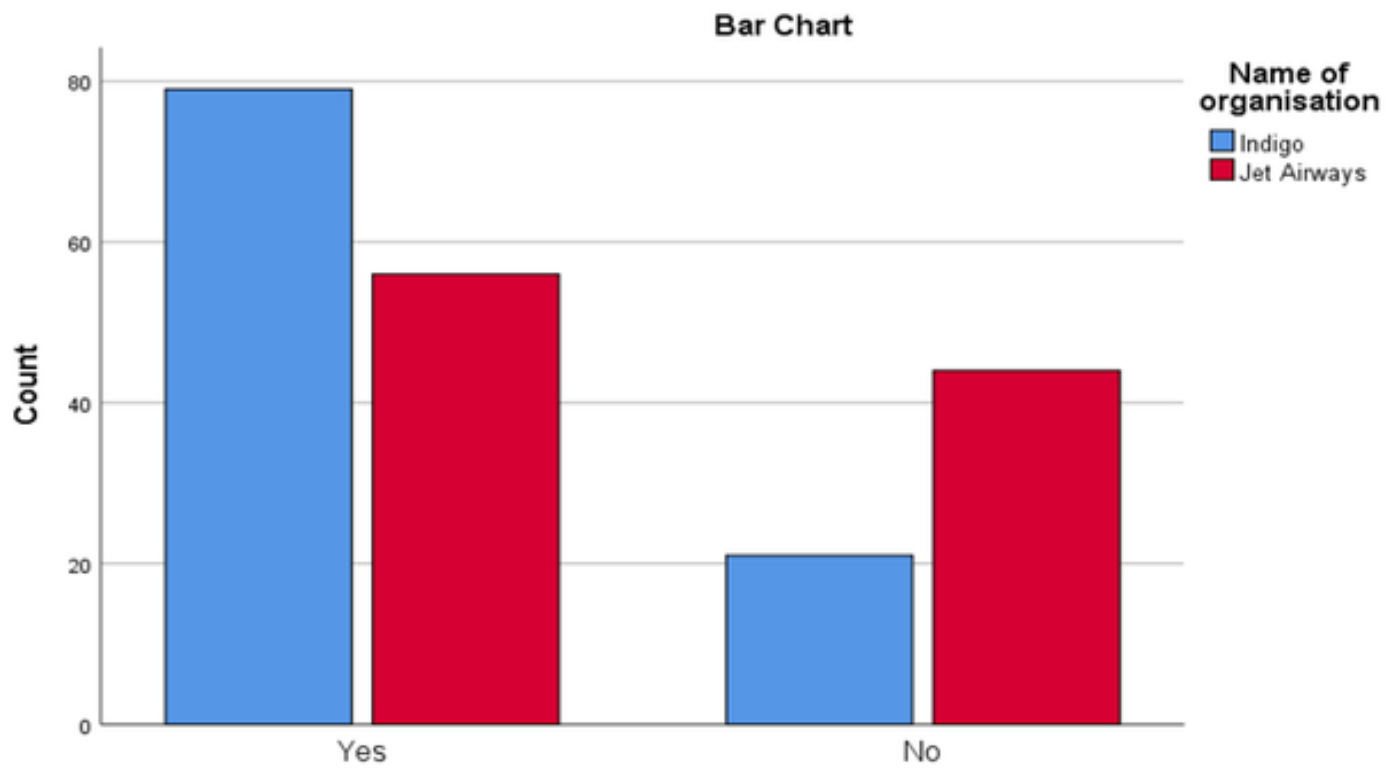

Do you satisfied with your current salary structure?

- It clearly shows that $79 \%$ of employees of Indigo Airlines are satisfied with the current salary structure. In contrast, only $56 \%$ of employees of Jet Airways agreed with the statement. It shows that Indigo Airline employees are more satisfied than Jet Airways. Salary is a maintenance factor that results in employee satisfaction; thus, we can say Indigo employees are more satisfied in the workplace than Jet Airways employees.

There is always a positive impact of "pay" on employees. This tool can be used to increase employees' satisfaction level.

\section{Hypothesis (Physical Working Condition)}

H0: There is no difference between Jet Airways and Indigo Airline employees' motivation based on the "Physical working condition" factor.

Table 8. Mann-Whitney Test-Physical Working Condition

\begin{tabular}{|l|l|l|l|l|}
\hline \multicolumn{5}{|c|}{ Ranks } \\
\hline & \multicolumn{1}{|c|}{ Name of organisation } & \multicolumn{1}{|c|}{ N } & \multicolumn{1}{c|}{ Mean Rank } & \multicolumn{1}{c|}{ Sum of Ranks } \\
\hline \multirow{2}{*}{$\begin{array}{l}\text { How do you feel about the } \\
\begin{array}{l}\text { Physical working condition at } \\
\text { your place? }\end{array}\end{array}$} & Indigo & 100 & 76.60 & 7660.00 \\
\cline { 2 - 5 } & Jet Airways & 100 & 124.40 & 12440.00 \\
\cline { 2 - 5 } & Total & 200 & & \\
\hline
\end{tabular}


Table 9. Test Statistics-Physical Working Condition

\begin{tabular}{|c|c|}
\hline \multicolumn{2}{|c|}{ Test Statistics $^{\mathbf{a}}$} \\
\hline & $\begin{array}{l}\text { How do you feel about the Physical working } \\
\text { condition at your place? }\end{array}$ \\
\hline Mann-Whitney U & 2610.000 \\
\hline Wilcoxon W & 7660.000 \\
\hline Z & -6.089 \\
\hline Asymp. Sig. (2-tailed) & .000 \\
\hline
\end{tabular}

a. Grouping Variable: Name of organisation

Table 10. Cross tab-Physical Working Condition

\begin{tabular}{|c|c|c|c|c|c|c|c|c|}
\hline \multicolumn{9}{|c|}{ Name of organisation* How do you feel about the Physical working condition at your place? Cross tabulation } \\
\hline & & & \multicolumn{5}{|c|}{$\begin{array}{l}\text { How do you feel about the Physical working condition at } \\
\text { your place? }\end{array}$} & \multirow{2}{*}{ Total } \\
\hline & & & $\begin{array}{l}\text { Extremely } \\
\text { good }\end{array}$ & Good & Neutral & Bad & $\begin{array}{c}\text { Extremely } \\
\text { bad }\end{array}$ & \\
\hline \multirow{6}{*}{$\begin{array}{l}\text { Name of } \\
\text { Organisation }\end{array}$} & \multirow{3}{*}{ Indigo } & Count & 58 & 20 & 9 & 7 & 6 & 100 \\
\hline & & $\begin{array}{l}\% \text { within Name } \\
\text { of organisation }\end{array}$ & $58.0 \%$ & $20.0 \%$ & $9.0 \%$ & $7.0 \%$ & $6.0 \%$ & $100.0 \%$ \\
\hline & & $\%$ of Total & $29.0 \%$ & $10.0 \%$ & $4.5 \%$ & $3.5 \%$ & $3.0 \%$ & $50.0 \%$ \\
\hline & \multirow{3}{*}{$\begin{array}{l}\text { Jet } \\
\text { Airways }\end{array}$} & Count & 8 & 37 & 46 & 4 & 5 & 100 \\
\hline & & $\begin{array}{l}\% \text { within Name } \\
\text { of organisation }\end{array}$ & $8.0 \%$ & $37.0 \%$ & $46.0 \%$ & $4.0 \%$ & $5.0 \%$ & $100.0 \%$ \\
\hline & & $\%$ of Total & $4.0 \%$ & $18.5 \%$ & $23.0 \%$ & $2.0 \%$ & $2.5 \%$ & $50.0 \%$ \\
\hline \multirow{3}{*}{ Total } & & Count & 66 & 57 & 55 & 11 & 11 & 200 \\
\hline & & $\begin{array}{l}\% \text { within Name } \\
\text { of organisation }\end{array}$ & $33.0 \%$ & $28.5 \%$ & $27.5 \%$ & $5.5 \%$ & $5.5 \%$ & $100.0 \%$ \\
\hline & & $\%$ of Total & $33.0 \%$ & $28.5 \%$ & $27.5 \%$ & $5.5 \%$ & $5.5 \%$ & $100.0 \%$ \\
\hline
\end{tabular}

Source: (Data Collected through a questionnaire at Lucknow Airport, 2018)

\section{Interpretation (Physical Working Conditions)}

The result suggests that the Mann Whitney $U$ test is at a significant level. Thus the null hypothesis is rejected, and the alternate hypothesis is accepted at a 5\% level of significance or $95 \%$ confidence level. The result shows a significant difference based on the "Physical working condition" provided by Indigo and Jet Airways to their employees.

- Tabulated P value is $0.00<0.05->$ statistically significant difference.

- Indigo employees seem much more motivated about "Physical working conditions" than Jet Airways employees.

- It clearly shows that $58 \%$ of Indigo Airline employees said the physical working condition is extremely good. In contrast, only $46 \%$ of Jet employees were neutral in their responses statement. 


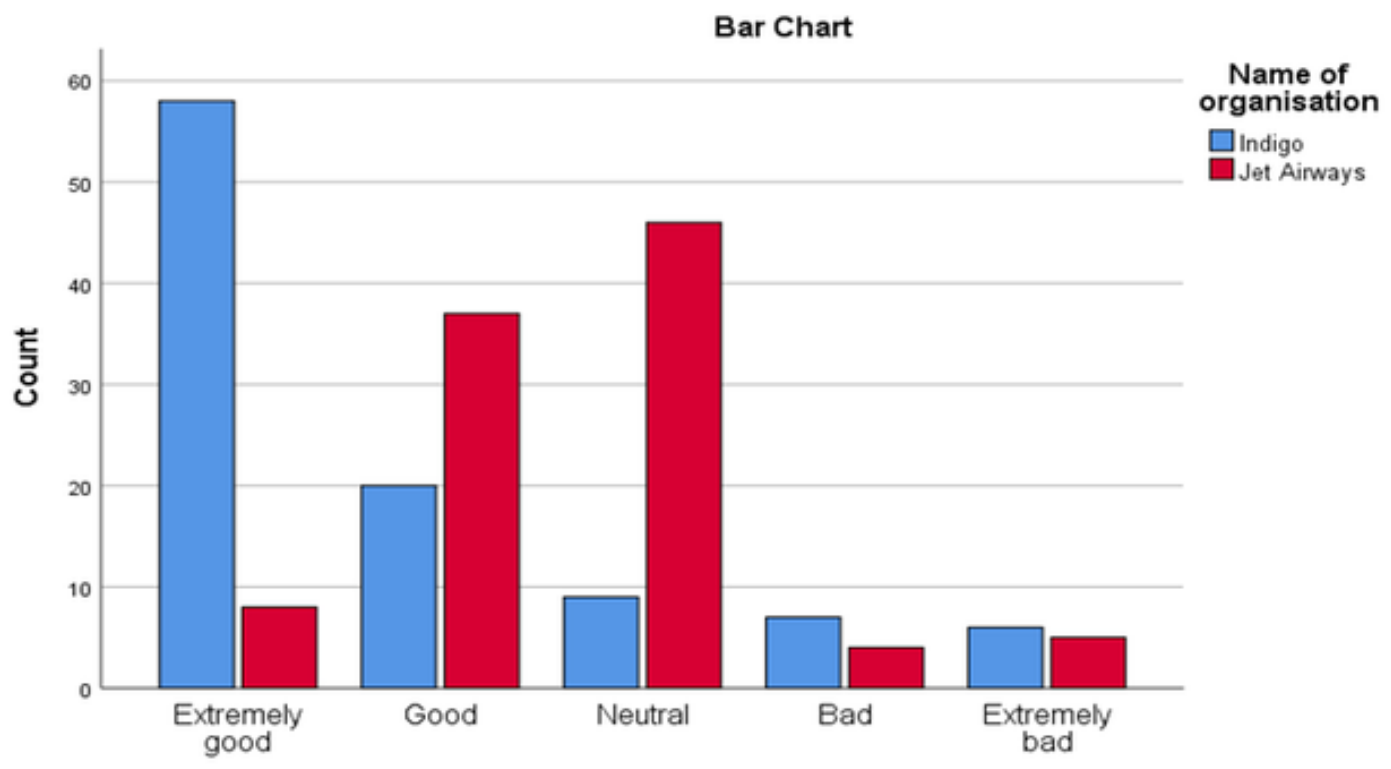

How do you feel about the Physical working condition at your place?

Physical working condition is a maintenance factor that results in employee satisfaction; thus, we can say Indigo employees are more satisfied as the physical working condition is extremely good at the workplace than Jet Airways employees.

There is always a positive impact of maintenance factors on employees. This tool can be used to increase employees' satisfaction level.

\section{Hypothesis (Job Security)}

H0: There is no difference between Jet Airways and Indigo Airline employees' motivation based on the "Job Security" factor.

\section{Interpretation (Job Security)}

The result suggests that the Mann Whitney $U$ test is at a significant level. Thus the null hypothesis is rejected, and the alternate hypothesis is accepted at a 5\% level of significance or $95 \%$ confidence level. The result shows a significant difference based on the "sense of Job Security "provided by Indigo and Jet Airways to their employees.

Table 12. Mann-Whitney Test-Job Security

\begin{tabular}{|l|l|l|l|l|}
\hline \multicolumn{5}{|c|}{ Ranks } \\
\hline & \multicolumn{1}{|c|}{ Name of Organisation } & \multicolumn{1}{|c|}{ N } & \multicolumn{1}{c|}{ Mean Rank } & Sum of Ranks \\
\hline \multirow{3}{*}{$\begin{array}{l}\text { Do you get a sense of job } \\
\text { security at your workplace? }\end{array}$} & Indigo & 100 & 86.50 & 8650.00 \\
\cline { 2 - 5 } & Jet Airways & 100 & 114.50 & 11450.00 \\
\cline { 2 - 5 } & Total & 200 & & \\
\hline
\end{tabular}


Table 13. Test Statistics-Job Security

\begin{tabular}{|l|l|}
\hline \multicolumn{2}{|c|}{ Test Statistics $^{\text {a }}$} \\
\hline Mann-Whitney U & \multicolumn{1}{|c|}{ Do you get a sense of job security at your } \\
workplace?
\end{tabular}

a. Grouping Variable: Name of organisation

Table 14. Cross tab-Job Security

\begin{tabular}{|c|c|c|c|c|c|}
\hline \multicolumn{6}{|c|}{ Name of organisation * Do you get a sense of job security at your workplace? Cross tabulation } \\
\hline & & & \multicolumn{2}{|c|}{$\begin{array}{c}\text { Do you get a sense of job } \\
\text { security at your workplace? }\end{array}$} & \multirow{2}{*}{ Total } \\
\hline & & & Yes & No & \\
\hline \multirow{6}{*}{ Name of Organisation } & \multirow{3}{*}{ Indigo } & Count & 75 & 25 & 100 \\
\hline & & $\begin{array}{l}\% \text { within Name of } \\
\text { organisation }\end{array}$ & $75.0 \%$ & $25.0 \%$ & $100.0 \%$ \\
\hline & & $\%$ of Total & $37.5 \%$ & $12.5 \%$ & $50.0 \%$ \\
\hline & \multirow{3}{*}{ Jet Airways } & Count & 47 & 53 & 100 \\
\hline & & $\begin{array}{l}\% \text { within Name of } \\
\text { organisation }\end{array}$ & $47.0 \%$ & $53.0 \%$ & $100.0 \%$ \\
\hline & & $\%$ of Total & $23.5 \%$ & $26.5 \%$ & $50.0 \%$ \\
\hline \multirow{3}{*}{\multicolumn{2}{|c|}{ Total }} & Count & 122 & 78 & 200 \\
\hline & & $\begin{array}{l}\% \text { within Name of } \\
\text { organisation }\end{array}$ & $61.0 \%$ & $39.0 \%$ & $100.0 \%$ \\
\hline & & $\%$ of Total & $61.0 \%$ & $39.0 \%$ & $100.0 \%$ \\
\hline
\end{tabular}

Source: (Data Collected through a questionnaire at Lucknow Airport, 2018)

- Tabulated $\mathrm{P}$ value is $0.00<0.05$.

- It clearly shows that $75 \%$ of employees agreed that they get a sense of job security while working with Indigo Airline. In contrast, only $47 \%$ of employees of Jet Airways agreed with the statement.

- Indigo employees seem much more motivated about "Job Security" than Jet Airways employees.

A sense of job security is a maintenance factor that results in employee satisfaction; thus, we can say Indigo employees are more satisfied as job security at the workplace is more than Jet Airways.

There is always a positive impact on job security factors on employees. This tool can be used to increase employees' morale.

\section{FINDINGS}

Findings based on different Hygiene factors have been stated below are as follows. 


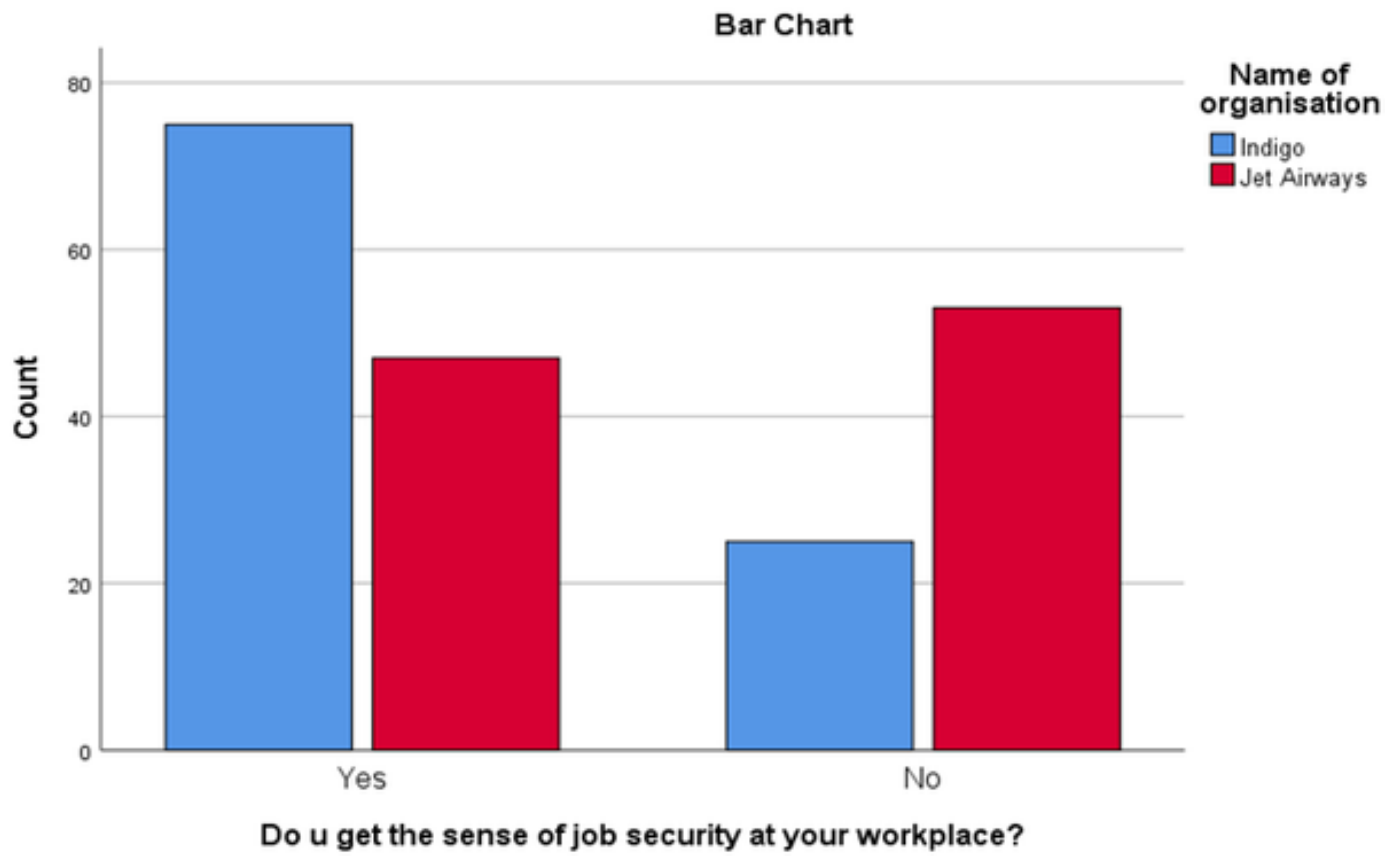

\section{Quality of Supervision}

- Indigo employees' work gets supervised frequently than Jet airways employees.

- It clearly shows that $68 \%$ of employees of Indigo Airlines said their work always gets supervised frequently. In contrast, only $71 \%$ of employees of Jet Airways affirmed that their work gets supervised occasionally.

- Supervision is a maintenance factor that results in employee satisfaction; thus, we can say Indigo employees are more satisfied in terms of supervision at the workplace than Jet Airways employees.

\section{Salary Structure}

- Indigo employees seem more motivated about "Salary Structure" than Jet Airways employees.

- It clearly shows that $79 \%$ of employees of Indigo Airlines are satisfied with the current salary structure. In contrast, only $56 \%$ of employees of Jet Airways agreed with the statement. It shows that Indigo Airline employees are more satisfied than Jet Airways. Salary is a maintenance factor that results in employee satisfaction; thus, we can say Indigo employees are more satisfied with the workplace than Jet Airways employees.

- There is always a positive impact of "Salary Structure" on employees. This tool can be used to increase employees' satisfaction level.

\section{Physical Working Conditions}

- Indigo employees seem much more motivated about "Physical working conditions" than Jet Airways employees.

- It clearly shows that $58 \%$ of Indigo Airline employees said the physical working condition is extremely good. In contrast, only $46 \%$ of Jet employees were neutral in their responses statement. 
- Physical working condition is a maintenance factor that results in employee satisfaction; thus, we can say Indigo employees are more satisfied as the physical working condition is extremely good at the workplace than Jet Airways employees.

- There is always a positive impact of maintenance factors on employees. This tool can be used to increase employees' satisfaction level.

\section{Job Security}

- It clearly shows that $75 \%$ of employees agreed that they get a sense of job security while working with Indigo Airline. In contrast, only $47 \%$ of employees of Jet Airways agreed with the statement.

- Indigo employees seem much more motivated about "Job Security" than Jet Airways employees.

- A sense of job security is a maintenance factor that results in employee satisfaction; thus, we can say Indigo employees are more satisfied as job security at the workplace is more than Jet Airways.

- There is always a positive impact on employees' job security factors. This tool can be used to increase employees' morale.

- Based on the above factors, we conclude that the alternate hypothesis has been accepted at a 5\% level of significance.

- The result suggests that the Mann Whitney U Test is at a significant level. Thus the null hypothesis is rejected, and the alternate hypothesis is accepted at a 5\% level of significance or $95 \%$ confidence level.

- Hence we conclude that Indigo Airline employee seems much more motivated than Jet Airways employees based on Hygiene factors.

- Hence we conclude that "Hygiene Factors - Herzberg Two Factor Theory" positively impacts airline employees' retention.

\section{CONCLUSION}

The study found that physical working conditions, salary structure, supervision at the workplace, and Job security significantly affect and positively impact employee retention in Jet Airways and Indigo airlines. Therefore it is recommended that these hygiene factors be considered for employees to boost their decision to stay with the organization. Consequently, it is advised that both the organization's policymakers should give them these facilities to increase their motivational level, which eventually results in employee retention and cut the employee turnover rate. The questionnaire has also discussed the Hygiene Factor of motivation. Comparison has been made based on the quality of supervision, pay, physical working condition, job security, etc.

Based on the comparison, it has been found that Indigo employees are more satisfied in terms of quality of supervision, salary structure, physical working condition, and job security than Jet Airways employees.

\section{RECOMMENDATIONS}

Airlines should take an outcome into account. The management team or human resource department, especially the HR director, should also emphasize proper understanding of the employees' retention strategies in-depth details and employees' perspectives such as their needs and wants to enhance with strategies or interventions. Human resource practices need to improve to retain their employees' overtime to gain more effectiveness and efficiency in the employees' management. Moreover, the organisation's turnover rate needs to be constantly monitored and prepared in all strategies. The vital employees' turnover establishes several of the highest organisation's losses and costs, such as potential employees, training, and recruitment. 
From the above discussion, it is found that employee attrition is a serious issue in the Airline industry.

\section{Organisation Policy}

Policies can protect the organization from legal problems, ensure fair treatment for employees, and establish consistent work standards, rules, and regulations.

\section{Compensation}

There are various reasons responsible for employee attrition:-dissatisfaction with internal job postings (unwanted posting), unnecessary transfer, work profile, designations, and related key responsibility areas, unclear job description, and finally, dissatisfaction with payment/ wages salary. Therefore, better retention is required to improve pay/compensation and benefits and factors like motivators and hygiene factors (Herzberg Theory), including good working conditions, flexible working hours, cooperative groups and supportive management, sensible and responsible bosses, and organisation culture.

\section{Physical Working Condition}

The work environment is conducive, among many other things, when the management knows where it is headed when the organization has strong ethics and culture when Monday morning blues are only limited to what to wear to work when people feel like they belong there when they see that everyone is treated just and when communication flows easily.

\section{Leadership Style}

Any organisation's goal is not to survive in the market but to make its existence by improving performance. It can only happen when bosses act and influence like a real leader who gives tasks and equally helps perform duties and supports employees' decisions. The role of leadership is critically important for organisational performance and employee retention. It is then no wonder that his satisfaction level at work is directly proportional to his work-equation with his manager.

\section{Communication}

Workplace communication is very important to companies because it allows companies to be productive and operate effectively. Employees can increase morale, productivity, and commitment to communicate up and down the organisation's communication chain.

\section{SCOPE FOR FUTURE STUDY}

The present study consists of limited employee retention strategies and variables. It creates an opportunity for future research in this area by considering other variables:

- Future research can examine other possible directions and compare the other factors like Extrinsic, Intrinsic motivational factors that influence employee motivation and retention.

- This study is limited to Lucknow airport employees only so that further work can be done on other Airline ground staff employees belonging to different cities in Uttar Pradesh as well as in other states in India.

- Hotel Industry has close similarities with the Aviation industry with equally alarming attrition rates. Further work can be done in the same sector. However, it is controversial whether employees of other sectors may face the same problem and difficulties which result in employee dissatisfaction and turnover.

- A comprehensive comparison of employees of other service industry sectors of different countries can also be further researched. A strategic model can also be constructed. 


\section{LIMITATIONS OF THE STUDY}

- The employees' attitude and opinion may change in the future, so the future relevance of the study cannot be assured.

- Some of the respondents did not answer the question seriously.

- Few respondents were hesitated to express their opinion; hence attaining accurate result is not possible.

- A problem like incompleteness of information was confronted during the data and information collection exercise.

- Biasness on the part of responses: some respondents were not ready to reveal the true information.

- Lack of reliable data: on every step of data collection, proper precautions have been taken, but a hundred percent reliability of the responses cannot be assured. Nobody can judge the respondent's behavior when he/she is going to give an unrealistic or biased answer. So throughout the research, there is a feeling of getting unrealistic data by some respondents. 


\section{REFERENCES}

Ahammad, M. F., Tarba, S. Y., Liu, Y., \& Glaister, K. W. (2016). Knowledge transfer and cross-border acquisition performance: The impact of cultural distance and employee retention. International Business Review, 25(1), 66-75. doi:10.1016/j.ibusrev.2014.06.015

Ahlrichs, N. S. (2000). Competing for talent: Key recruitment and retention strategies for becoming an employer of choice. Davies-Black Publications.

Alafeshat, R., \& Tanova, C. (2019). Servant Leadership Style and High-Performance Work System Practices: Pathway to a Sustainable Jordanian Airline Industry. Sustainability, 11(22), 6191. doi:10.3390/su11226191

Bazan, C. (2011). Measuring Employee Retention in WIPO. WIPO.

Boswell, W. R., Gardner, R. G., \& Wang, J. (2017). Is retention necessarily a win? Outcomes of searching and staying. Journal of Vocational Behavior, 98, 163-172. doi:10.1016/j.jvb.2016.11.006

Collins, C. (2007). The interactive effects of recruitment practices and product awareness on job seekers employer knowledge and application behaviors. The Journal of Applied Psychology, 92(1), 180-192. doi:10.1037/00219010.92.1.180 PMID:17227159

Employee retention. (2017). En.wikipedia.org. Retrieved from https://en.wikipedia.org/wiki/Employee_retention

Ground Staff Job Description. (2019). Betterteam. Retrieved from https://www.betterteam.com/ground-staffjob-description

Herzberg, F., Mausner, B., \& Snyderman, B. (1959). The Motivation to Work. Second edition. New York: Chapman \& Hall.

Indian Aviation Industry I Aviation Industry at A Glance in 2019-2020. (2020). Indianmirror.com. Retrieved from https://www.indianmirror.com/indian-industries/2020/aviation-2020.html

IndiGo. (2020). En.wikipedia.org. Retrieved from https://en.wikipedia.org/wiki/6E_fleet

Jet Airways. (2017). En.wikipedia.org. Retrieved from https://en.wikipedia.org/wiki/Jet_Lite_(India)_Ltd

Karatepe, O. M. (2016). The effect of psychological climate on job outcomes: Evidence from the airline industry. Journal of Travel \& Tourism Marketing, 33(8), 1162-1180. doi:10.1080/10548408.2015.1094002

Kreitner, R., \& Kinicki, A. (2012). Organisational Behavior. McGraw-Hill Higher Education.

Mehta, P. (2020). Exploring the association between demographic and job satisfaction of employees working in civil aviation industry. TRANS Asian Journal of Marketing \& Management Research, 9(6), 31-40.

Memon, S. P. (2010). Investigating the Mediating Role of Human Resource Policies in Employee Retention. Australian Journal of Basic and Applied Sciences, 4(8), 42046-44057.

Mitchell, T. (1982). Motivation: New Directions for Theory, Research, and Practice. Academy of Management Review, 7(1), 80-88. doi:10.5465/amr.1982.4285467

Ongori, H. (2008). A review of the Literature on Employee Turnover. African Journal of Business Management, $1(3), 1-54$.

Ranjbar, M., \& Amiri, N. (2015). The Relationship between Knowledge Management and Employee Retention. Proceedings of the IRES 7th International Conference.

Ritz, A., Brewer, G. A., \& Neumann, O. (2016). Public service motivation: A systematic literature review and outlook. Public Administration Review, 76(3), 414-426. doi:10.1111/puar.12505

Robbins, S., \& Judge, T. (2007). Organisational behavior. Pearson/Prentice Hall.

Robinson, R. N., Kralj, A., Solnet, D. J., Goh, E., \& Callan, V. (2014). Thinking job embeddedness, not turnover: Towards a better understanding of frontline hotel worker retention. International Journal of Hospitality Management, 36, 101-119. doi:10.1016/j.ijhm.2013.08.008 
Roodt, G., \& Kotze, K. (2005). Factors that affect the retention of managerial and specialist staff: An exploratory study of an employee commitment model. SA Journal of Human Resource Management, 3(2), 48-55.

Said, M. (2012). Factors Influencing Employees' Retention in Public and Private Sector Work Organizations in Tanzania (Master in Business Administration). Open University of Tanzania.

Satardien, M., Jano, R., \& Mahembe, B. (2019). The relationship between perceived organisational support, organisational commitment and turnover intention among employees in a selected organisation in the aviation industry. SA Journal of Human Resource Management, 17, 8. doi:10.4102/sajhrm.v17i0.1123

Siddiqui, N. N., \& Bisaria, G. (2018). Innovative Techniques of Motivation for Employee Retention in Aviation Industry. ANVESHAK-International Journal of Management, 7(1), 136-151.

Siddiqui, N. N., \& Bisaria, G. (2019). Empirical Study on Innovative Techniques of Motivation for Employee Retention: Comparative Study of Jet Airways and Indigo Airlines at Lucknow. A Journal of Composition Theory, 12(7), 145-156.

Siddiqui, N. N., \& Bisaria, G. (2019). Empirical Study on Innovative Techniques of Motivation for Employee Retention: A Comparative Study of Jet Airways and Indigo Airline. Universal Review, 10(5), $250-261$.

Terera, S. R., \& Ngirande, H. (2014). The impact of rewards on job satisfaction and employee retention. Mediterranean Journal of Social Sciences, 5(1), 481. doi:10.5901/mjss.2014.v5n1p481

Turney, M. A. (Ed.). (2017). Tapping diverse talent in aviation: Culture, gender, and diversity. Routledge. doi: $10.4324 / 9781315241807$

Uniyal, M., Banerjee, S., \& Roy, K. (2018). Relationship between Job Embeddedness and Employees Turnover Intention: A Study on Private Airlines in India. Journal of Strategic Human Resource Management, 7(3), 9.

Zarim, Z. A. (2017). The Role of Organisational Commitment, Leadership Style, Strategic Human Resources Practices and Job. Springer International Publishing.

Zheng, C. K. (2016). The impact of individual coping strategies and organizational work-life balance programmes on Australian employee well-being. International Journal of Human Resource Management, 27(5), 501-526.

Neha Nazneen Siddiqui is pursuing PhD in Management from Integral University, Kursi Road, Lucknow, India. Her research Interests are in the area of Employee motivation and retention. She has published around 10 research papers in various International Journals and Conferences.

Gaurav Bisaria is working as an Assistant Professor in the Department of Commerce and Business Management, Integral University, Lucknow. He has a specialization in Marketing Management. He is having teaching experience of 20 years. He has published various papers in National and International Journals. 